\title{
Paraquat-induced Thrombotic Microangiopathy: The Pathophysiology in Hyperacute Paraquat Poisoning Deaths
}

\author{
H Daisley Jr, A Rampersad, O Acco, D Meyers
}

\begin{abstract}
This paper described the pathophysiology of suicide deaths from paraquat poisoning which occurred in patients who died in fewer than 24 hours after ingesting paraquat. These deaths were referred to as hyperacute paraquat poisoning deaths. Thrombotic microangiopathy was the predominant pathological finding in all these cases and was evident in the brain, lung, heart, kidneys and in all organs and tissues examined. Of note, diffuse alveolar capillary thrombosis occurred, causing damage to alveolar walls, including those in subpleural locations, resulting in focal visceral pleural rupture leading to pneumothorax and pneumomediastinum in these cases, thus giving rise to yet another mechanism of pneumothorax and pneumomediastinum in paraquat toxicity. Thrombotic microangiopathy is the major pathological mechanism that underlies paraquat poisoning and has not hitherto been reported.
\end{abstract}

Keywords: Hyperacute paraquat poisoning, thrombotic microangiopathy

\section{Microangiopatía trombótica inducida por paraquat: fisiopatología de las muertes por envenenamiento hiperagudo con paraquat}

H Daisley Jr, A Rampersad, O Acco, D Meyers

\begin{abstract}
RESUMEN
El presente trabajo describe la fisiopatología de las muertes por suicidio por intoxicación con paraquat en pacientes que murieron en menos de 24 horas después de ingerirlo. Estas muertes fueron referidas como muertes por envenenamiento hiperagudo con paraquat. La microangiopatía trombótica fue el hallazgo patológico predominante en todos estos casos, y se hizo evidente en el cerebro, el pulmón, el corazón, los riñones y en todos los órganos y los tejidos examinados. Es de notar que se produjo una trombosis capilar alveolar difusa, que causó daño a las paredes alveolares, incluyendo aquellas en localizaciones subpleurales. Esto trajo como resultado la ruptura pleural visceral focal que condujo al neumotórax y al neumomediastino en estos casos, dando así lugar a otro mecanismo de neumotórax y neumomediastino en la toxicidad del paraquat. La microangiopatía trombótica es el mecanismo patológico principal que subyace en el envenenamiento por paraquat, y no ha sido reportada hasta el momento.
\end{abstract}

Palabras clave: Intoxicación hiperaguda por paraquat, microangiopatía trombótica

From: Department of Pathology, San Fernando General Hospital, San Fernando, Trinidad and Tobago, West Indies.
Correspondence: Professor H Daisley Jr, San Fernando General Hospital, San Fernando, Trinidad and Tobago, West Indies. Email: profhdjr@aol.com 


\section{INTRODUCTION}

A major focus in paraquat poisoning has been centred on the changes in the lung. Nicotinamide-adenine dinucleotide phosphate and paraquat redox cycle with the formation of superoxide radicles have dominated the literature in intractable pulmonary fibrosis $(1,2)$.

The role of nitric oxide in paraquat toxicity has also been a subject of discussion. Endothelial cells produce nitric oxide, and its low level maintains the integrity of endothelial cells. It is thought to modulate blood flow, thrombosis and neural activity.

In paraquat poisoning, nitric oxide (itself a free radicle) combines with another free radicle, superoxide anion, to form peroxynitrite, which causes oxidative cellular injury (3). Diminishing the concentration of nitric oxide as a result of its consumption by superoxide radicle reaction in paraquat poisoning also exposes endothelial cells to injury by the direct toxic effect of paraquat or as a result of idiosyncratic reaction with the resultant release of von Willebrand Factor (VWF) and vascular thrombosis (4).

Pulmonary capillary thrombosis has been reported in paraquat poisoning in the Daisley Barton syndrome (5). However, much attention was not focussed on these as other pathological events (such as pulmonary fibrosis and inflammation) dominated the lung pathology. Thrombotic microangiopathy is a major pathological finding and is the cause of death in hyperacute paraquat poisoning deaths. Therapy in paraquat poisoning was centred on suppressing the inflammatory response in the lung in an effort to prevent pulmonary fibrosis. With the discovery that thrombotic microangiopathy is the major pathological finding in hyperacute paraquat toxicity, therapy should instead be directed against thrombotic microangiopathy.

\section{SUBJECTS AND METHODS}

The authors observed that suicide victims who ingested large doses of paraquat of $100 \mathrm{ml}$ or more died of multiorgan failure within 24 hours of ingestion. Death was not prolonged over a period of days or weeks. The authors were of the view that the cardiorespiratory and central nervous systems had to be involved in these hyperacute paraquat poisoning deaths. It was postulated that the brain stem that housed the cardiac and respiratory centres must be involved to cause acute cardiorespiratory arrest and death. Complete autopsies were conducted in these five cases that occurred between January and March 2018, and samples of brain stem in each of these cases were examined histologically, not excluding other areas of the brain such as the cerebellum. Tissue samples were examined from the kidneys, lungs, heart and other areas using the haematoxylin and eosin stain.

\section{RESULTS}

Figures 1-8 show haematoxylin and eosin sections from the kidney: the glomerulus (Fig. 1), vasa recta (Fig. 2), the alveolar wall (Figs. 3, 4), the brain (Figs. 5-7) and the myocardium (Fig. 8).

The histological sections show microthrombi in the kidney, alveolar capillary, the brain stem, the cerebellum and the myocardium.

Fig. 4 shows the subpleural destruction of the alveolar wall with emphysematous change resulting in rupture of visceral pleura leading to pneumothorax.

Fig. 7 shows infarction of the brain stem.

\section{DISCUSSION}

Thrombotic microangiopathy manifests itself by the occurrence of widespread hyaline thrombi in terminal arterioles and capillaries in multiple organs. This was seen in the organs examined in hyperacute paraquat deaths listed in Table 1 and Figs. 1-6, 8.

Table 1: Five cases of hyperacute paraquat deaths between January and March 2018

\begin{tabular}{ccc}
\hline $\begin{array}{c}\text { Age of deceased } \\
\text { (years) }\end{array}$ & Gender & $\begin{array}{c}\text { Number of hours between } \\
\text { ingestion and death }\end{array}$ \\
\hline 18 & Female & 14 \\
62 & Male & 15 \\
64 & Male & 8 \\
68 & Male & 4 \\
43 & Male & 5 \\
\hline
\end{tabular}

These microthrombi are thought to consist primarily of VWF and platelets. In addition to serving as a carrier of factor VIII, VWF is the ligand for mediating platelet adhesion and aggregation at sites of vessel injury (4). Von Willebrand factor is synthesized in vascular endothelial cells and megakaryocytes and released in plasma and the subendothelium in some vessels. In the circulation, von Willebrand polymer is converted to plasma multimers by a plasma metalloprotease, namely ADAMTS13 $(6,7)$. This metallic protease regulates VWF and platelet aggregation by its cleavage function. Its deficiency causes VWF released in endothelial injury to bind avidly with platelets, promoting thrombotic microangiopathy.

Drug-induced thrombotic microangiopathy is well documented in the medical literature with the mechanism 


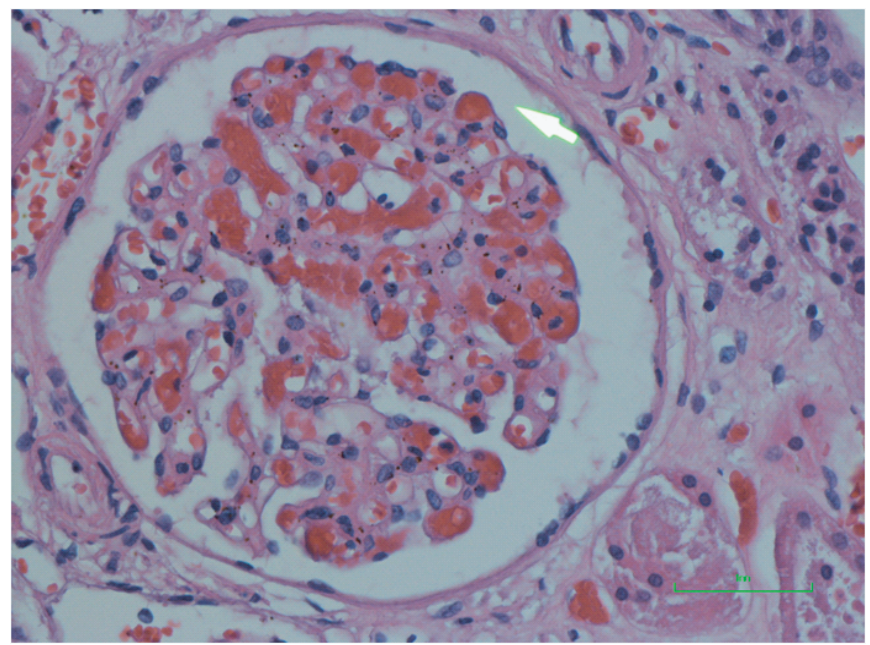

Fig. 1: Haematoxylin and eosin stain shows glomerulus with microthrombi within capillary loops.

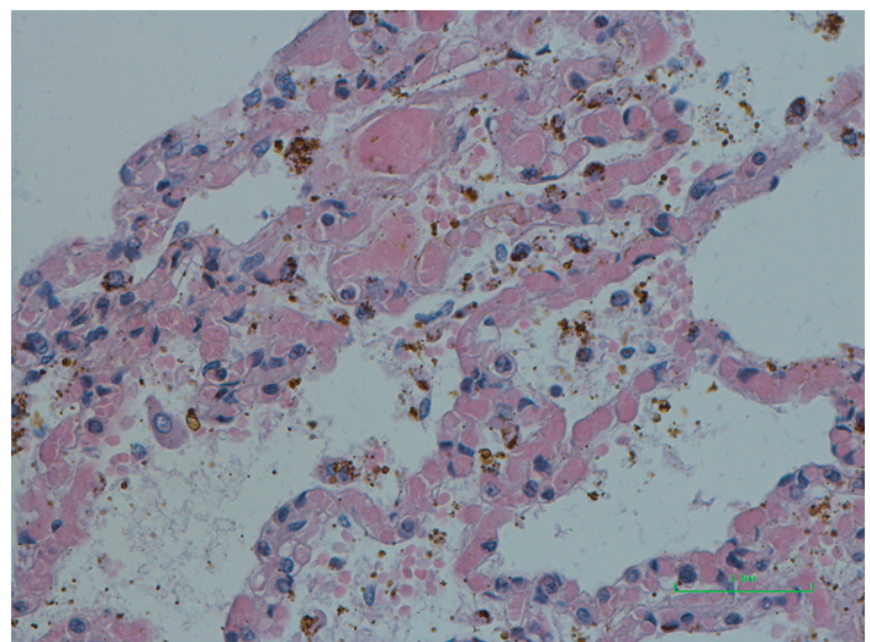

Fig. 3: Haematoxylin and eosin stain shows lung with thrombosis of alveolar capillaries.

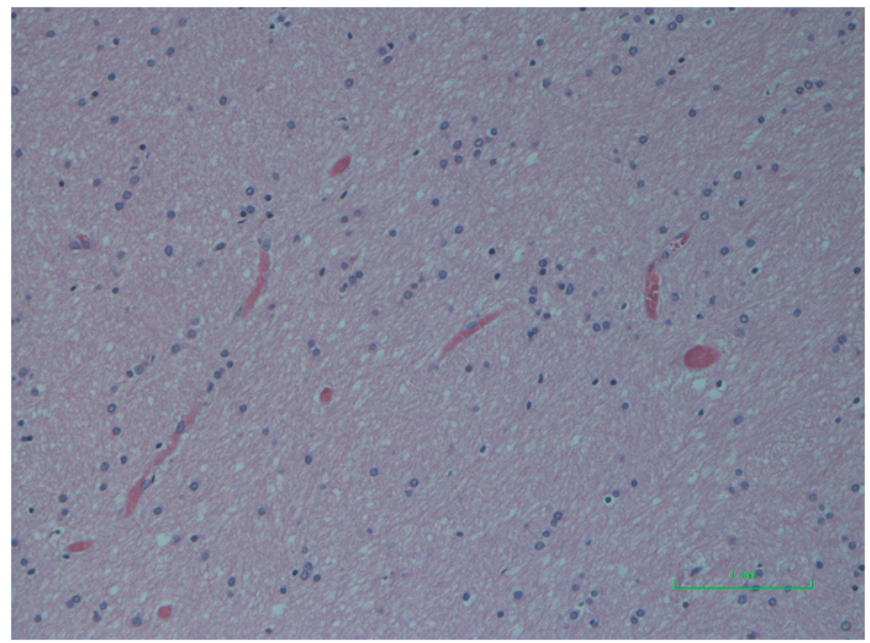

Fig. 5: Haematoxylin and eosin stain shows multiple microthrombi within the brain.

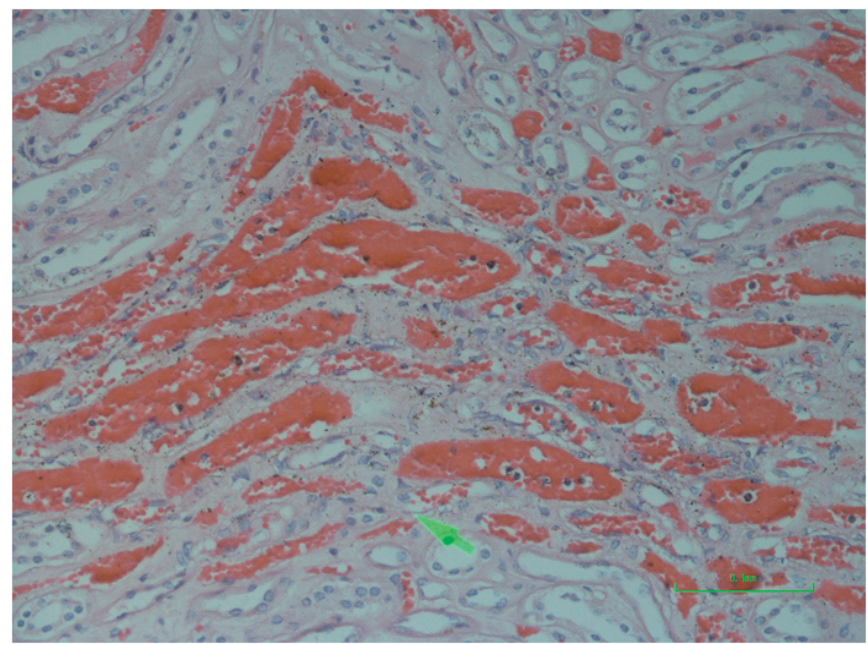

Fig. 2: Thrombosis within vasa recta.

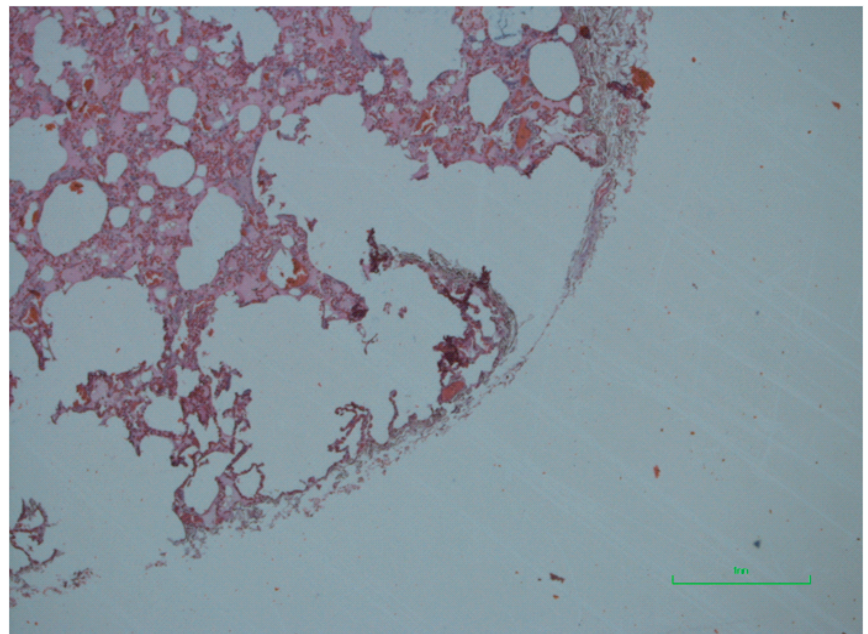

Fig. 4: Haematoxylin and eosin stain shows lung with thrombosis of alveolar capillary and emphysematous destruction of alveolar wall and subpleural rupture.

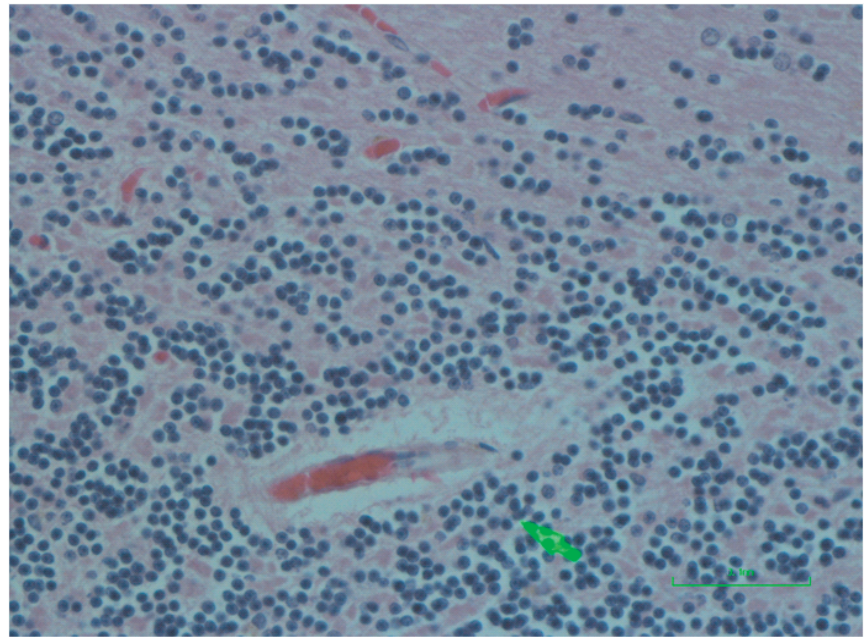

Fig. 6: Haematoxylin and eosin stain shows microthrombi within the cerebellum. 


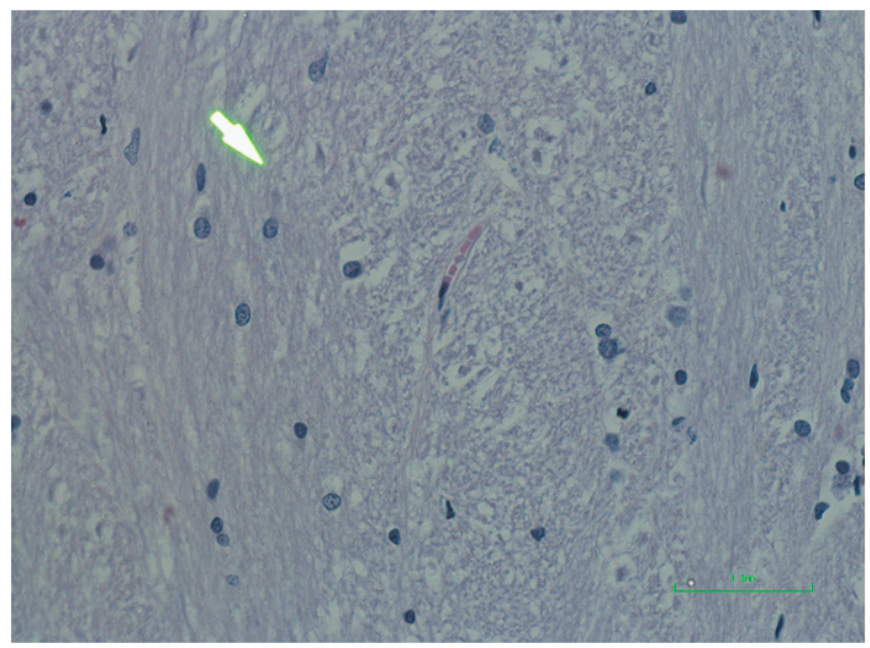

Fig. 7: Haematoxylin and eosin stain shows infarcted area of brain stem.

of microangiopathy postulated to occur as a result of a direct toxic drug effect which may be acute dose-related or idiosyncratic acute immunological reaction. In either event, endothelial cell damage is the trigger in these drug-related events that leads to thrombotic microangiopathy $(8,9)$.

Paraquat is toxic to endothelial cells and causes injury through the production of peroxynitrite $(3,10)$. Thrombotic microangiopathy is very evident in the lung terminal arterioles and alveolar capillaries (Fig. 3), since the concentration of paraquat in the lung is many times that in other tissues because of the selective concentration gradient that occurs in the lungs due to the polyamine transport system and also due to the lung being the major organ in which superoxide radicles are produced (11). Endothelial injury caused by paraquat leads to systemic microvascular thrombosis in arterioles and capillaries which causes multi-organ ischaemia, dysfunction and death. The overwhelming microvascular thrombosis in alveolar capillaries and terminal arterioles in the lung leads to diffuse destruction of the alveolar wall with emphysematous and atelectatic changes (Fig. 3), with respiratory failure in hyperacute paraquat poisoning.

Similar microthrombosis within the brain (Figs. 5, 6) caused microinfarction in the brain stem (Fig. 8), involving cardiorespiratory centres leading to cardiorespiratory arrest, coma and death.

Likewise, microthrombosis within glomerular capillary loops and vasa recta (Figs. 1,2) caused acute renal failure in hyperacute paraquat poisoning $(12,13)$.

The hyperacute injuries of thrombotic microangiopathy were seen in all tissues in this study, with the consumption of large volumes of paraquat. However,

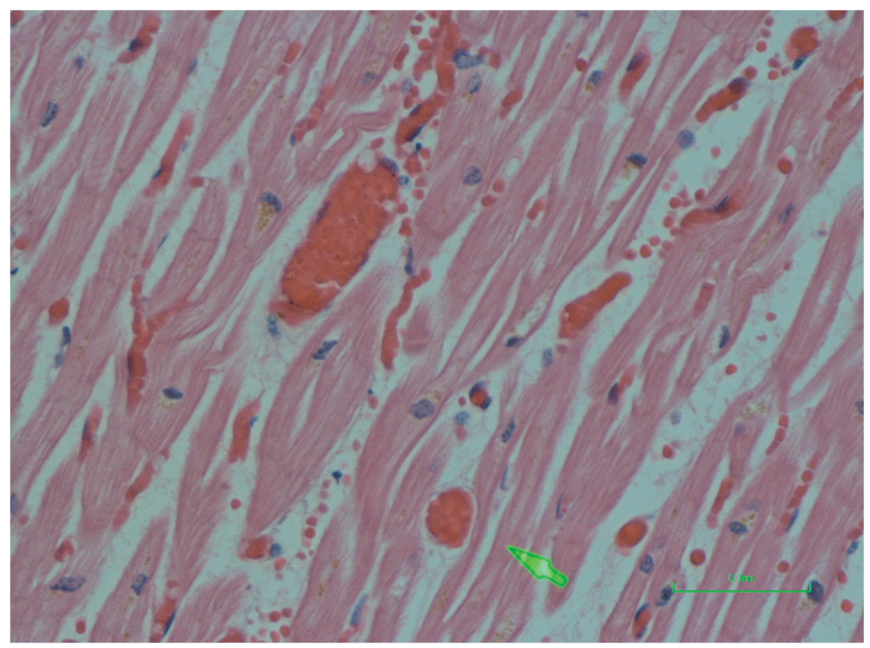

Fig. 8: Haematoxylin and eosin stain shows microthrombi within the myocardium.

ingestion of smaller volumes of paraquat also led to thrombotic microangiopathy, though to a lesser extent, as was seen in the lung - Daisley Barton Syndrome (5). The changes in the lung are to be expected even after the consumption of small doses of paraquat since the highest concentration of paraquat is always attained in the lung after any volume ingested, due to the selective concentration gradient that occurs in the lungs with the polyamine transport system and also due to the lung being the major organ in which superoxide radicles are produced (11). Hence, thrombotic microangiopathy is the major pathological event that occurs in paraquat poisoning. The other changes (eg the inflammatory response leading to pulmonary fibrosis) are secondary to the vascular/capillary damage caused by alveolar capillary thrombosis/microangiopathy.

Therapy directed at thrombotic microangiopathy (such as plasma exchange/plasma infusion) should be useful in treating paraquat toxicity $(6,12,14-16)$.

The administration of recombinant ADAMTS13 may serve as an additional therapeutic approach to prevent thrombotic events in hyperacute and acute paraquat toxicity (17).

\section{CONCLUSION}

Diffuse microthrombi were found in the brain, heart, lungs, kidneys and all other tissues in hyperacute paraquat poisoning deaths. Thrombotic microangiopathy is a major pathophysiological process that occurs in paraquat poisoning, and therapy should be directed against this process. Diffuse alveolar destruction and rupture of visceral pleura (Fig. 4) resulting in pneumothorax also occurred in hyperacute paraquat poisoning deaths. 
This is the first reported series of thrombotic microangiopathy occurring in paraquat poisoning.

\section{REFERENCES}

1. Blanco-Ayala T, Anderica-Romero AC, Pedraza-Chaverri J. New insights into antioxidant strategies against paraquat toxicity. Free Radic Res 2014; 489: 623-40.

2. Dou T, Yan M, Wang X, Lu W, Zhao L, Lou D et al. Nrf2/ARE pathway involved in oxidative stress induced by paraquat in human neural progenitor cells. Oxidative Medicine and Cellular Longevity 2016; article ID 8923860: 8 pages.

3. Pacher P, Beckman JS, Liaudet L. Nitric oxide and peroxynitrite in health and disease. Physiol Rev 2007; 87: 315-424.

4. Han-MOu T. Pathophysiology of thrombotic thrombocytopenic pupura. Int J Hematol 2010; 91: 1-19.

5. Meyers D, Rampersad A, Christopher M, Pegus S, Daisley H. Underdiagnosed paraquat induced pneumothorax and pneumomediastinum, the 'Daisley Barton Syndrome': a clinical feature of paraquat-induced acute lung injury. Int J Clin Pharmacol Toxicol 2018; 7: 296-9.

6. Wyrick-Glatzel J. Thrombotic thrombocytopenic pupura and ADAMTS13: new insights into pathogenesis, diagnosis and therapy. Labmedicine 2004; 35: 733-9.

7. Chapman K, Seldon M, Richards R. Thrombotic microangiopathies, thrombotic thrombocytopenic pupura, and ADAMTS13. Semin Thromb Hemost 2012; 38: 47-54.

8. Pisoni R, Ruggenenti P, Remuzzi G. Drug-induced thrombotic microangiopathy. Incidence, prevention and management. Drug Safety 2001; 24: 491-501.
9. Al-Nouri ZL, Reese JA, Terrell DR, Vesely SK, George JN. Druginduced thrombotic microangiopathy: a systematic review of published reports. Blood 2015; 125: 616-8.

10. Morán JM, Ortiz-Ortiz MA, Ruiz-Mesa LM, Fuentes JM. Nitric oxide in paraquat-mediated toxicity: a review. J Biochem Mol Toxicol 2010; 24: 402.

11. Smith LL, Lewis CPL, Wyatt I, Cohen GM. The importance of epithelial uptake systems in lung toxicity. Environmental Health Perspectives 1990; 85: 25-30.

12. Brocklebank V, Wood KM, Kavanagh D. Thrombotic microangiopathy and the kidney. CJASN 2018; 13: 197-9.

13. Jang HN, Bae EJ, Hwang K, Kang Y, Yun S, Cho HS et al. Hemolytic uremic syndrome associated with paraquat intoxication. J Clin Apher 2014; 29: 183-6.

14. Chen $\mathrm{C}, \mathrm{Wu} \mathrm{Y}$, Chien $\mathrm{S}$, Lin J. A survival case of intravenous paraquat intoxication: a case report. Medicine (Baltimore) 2018; 97: e11669.

15. Arnold DM, Patriquin CJ, Nazy I. Thrombotic microangiopathies: a general approach to diagnosis and management. CMAJ 2017; 189: E153-9.

16. Rao R, Bhat R, Pathadka S, Chenji SK, Dsouza S. Golden hours in severe paraquat poisoning - the role of early haemoperfusion therapy. J Clin Diagn Res 2017; 11: OC06-8.

17. Erpenbeck L, Demers M, Zsengellér ZK, Gallant M, Cifuni SM, Stillman IE et al. ADAMTS13 endopeptidase protects against vascular endothelial growth factor inhibitor-induced thrombotic microangiopathy. J Am Soc Nephrol 2016; 27: 120-31. 